\title{
Soil-strain compatibility: the key to effective use of arbuscular mycorrhizal inoculants?
}

\author{
Ricardo A. Herrera-Peraza • Chantal Hamel • \\ Félix Fernández • Roberto L. Ferrer • \\ Eduardo Furrazola
}

Received: 26 May 2009 / Accepted: 23 May 2010/Published online: 16 June 2010

(C) The Author(s) 2010. This article is published with open access at Springerlink.com

\begin{abstract}
Consistency of response to arbuscular mycorrhizal (AM) inoculation is required for efficient use of AM fungi in plant production. Here, we found that the response triggered in plants by an AM strain depends on the properties of the soil where it is introduced. Two data sets from 130 different experiments assessing the outcome of a total of 548 replicated single inoculation trials conducted either in soils with a history of (1) high input agriculture (HIA; 343 replicated trials) or (2) in more pristine soils from coffee plantations (CA; 205 replicated trials) were examined. Plant response to inoculation with different AM strains in CA soils planted with coffee was related to soil properties associated with soil types. The strains Glomus fasciculatum-like and Glomus etunicatum-like were particularly performant in soil relatively rich in nutrients and organic matter. Paraglomus occultum and Glomus mosseae-like performed best in relatively poor soils, and G. mosseae and Glomus manihotis did best in soils of medium fertility. Acaulospora scrobiculata, Diversispora spurca, G. mosseae-like, G. mosseae and P. occultum stimulated coffee growth best in Chromic, Eutric Alluvial Cambisol, G. fasciculatum-like and G. etunicatum-like in
\end{abstract}

R. A. Herrera-Peraza

Instituto de Ecología y Sistemática, IES, CITMA,

Havana, Cuba

C. Hamel $(\bowtie)$

Semiarid Prairie Agricultural Research Centre, AAFC,

PO Box 1030, Swift Current, SK S9H 3X2, Canada

e-mail: Chantal.Hamel@agr.gc.ca

F. Fernández $\cdot$ R. L. Ferrer $\cdot$ E. Furrazola

Department of Biofertilizer and Plant Nutrition,

Instituto Nacional de Ciencias Agrícolas,

San José de las Lajas, La Habana, Cuba
Calcaric Cambisol and G. manihotis, in Chromic, Eutric Cambisols. Acaulospora scrobiculata and Diversispora spurca strains performed best in Chromic Alisols and Rodic Ferralsols. There was no significant relationship between plant response to AM fungal strains and soil properties in the HIA soil data set, may be due to variation induced by the use of different host plant species and to modification of soil properties by a history of intensive production. Consideration of the performance of AM fungal strains in target soil environments may well be the key for efficient management of the AM symbiosis in plant production.

Keywords Adaptation - Effectiveness - Soil properties .

Soil type $\cdot$ Soil classification $\cdot$ AM inoculant .

Consistency of response

\section{Introduction}

The arbuscular mycorrhizal (AM) symbiosis has evolved in most terrestrial environments as an efficient system of phosphorus uptake in plants (Brundrett 2009). But despite increasing fertilizer costs and disappearing world phosphorus reserves (Gilbert 2009), progression in the use of the AM symbiosis in plant production has been slow. Although the causes of this poor performance have been diverse, it is true that the conditions for the expression of mycorrhizal effectiveness are poorly known, leading to inconsistency in response to AM inoculation (see Ryan and Graham 2002).

According to principles in ecology, the success of an AM symbiosis depends not only on the plant and fungal genotypes, but also on the conditions of the environment. The functional specificity that exists between plants and AM fungi has been documented (Helgason et al. 2002; 
Leake et al. 2004; Klironomos 2003). The soil environment certainly imposes a strong selection pressure on AM fungi (Hamel 2007; Helgason and Fitter 2009), but the influence of the soil on AM genotypes is ill understood (Feddermann et al. 2010).

The factors controlling the effectiveness of an AM fungal strains must be understood before reliable AM inoculation technologies for field crops can be produced, and the soil is likely a key determinant of AM fungi effectiveness. We know that plants influence importantly $\mathrm{AM}$ fungi through the provision of $\mathrm{C}$ substrate, but the influence of the soil on these fungi should not be overlooked. The soil not only provides mineral nutrients to AM fungi, but also constitutes the chemical and physical environment where both these fungi and their plant associates live.

There is much evidence supporting the hypothesis of a large influence of soil properties on AM fungi (Hamel et al. 1994; Frey and Ellis 1997; van Aarle et al. 2002; Johnson et al. 2005; Mechri et al. 2008; Gryndler et al. 2009). The properties and environment of a soil may have different influence on different AM isolates. Liming the soil decreased root colonization by Acaulospora laevis, but increased root colonization by G. invermaium in the same study (Sano et al. 2002) showing that different AM species have different soil $\mathrm{pH}$ optima. The adaptation of AM fungi to specific soil $\mathrm{pH}$ caused $\mathrm{AM}$ strains to exist only within a range of soil pH levels (Oehl et al. 2005). Soil $\mathrm{OM}$, available N-to-P ratio, bulk density, and $\mathrm{pH}$ drive changes in AM fungi community composition (Fitzsimons et al. 2008). It appears that AM strains may survive and function well only within a range of soil environmental conditions.

The effectiveness of AM symbioses created through plant inoculation may depend on the adaptation of the AM fungal strains used to the soil where they are introduced. We tested this hypothesis using data generated by an important research effort made between 1991 and 1993 in Cuba to develop AM fungi inoculation technologies. Here, we used multivariate analysis of data from 130 inoculation trials to reveal relationships existing between the plant response to inoculation with different AM fungal strains and soil properties. One analysis was performed on data from 62 experiments conducted in soils from high input cropping systems that yielded 343 data points (each one being the average of three, four or five replicates) expressing the responses of different crop plants to various AM strains formulated in MicoFert ${ }^{\circledR}$. Another analysis was performed on data from 68 experiments conducted in more pristine coffee plantation soils that yielded a total of 205 data points (which were averages of four replicates) representing coffee plant response to different AM strains.

\section{Materials and methods}

\section{Approach}

Our study is based on the results of 62 inoculation trials using soils from Cuban plains with a history of high input agriculture (HIA) management (Table 1) and 68 trials conducted with pristine or semi-natural soils, which were under low-input under-story coffee production, typically from mountainous areas (CA) (Table 2). The inoculation trials conducted using soils of the HIA and CA groups were evaluating AM fungal strains (Table 3 ) for their ability to enhance plant growth. Different crops were grown in HIA soils and coffee plants were grown in CA soils. These experiments are described in Tables 1 and 2 and in the text below. Additional information on these experiments can be found elsewhere (Fernández 1999). In all these experiments, plants were inoculated with different AM fungal strains with potential for use in inoculants, and their performance at stimulating plant growth was recorded. The indicator of AM fungal strain performance varied between experiments (Tables 1 and 2) as they were not initially meant for the meta-analyses reported here. Thus, the responses to inoculation generated by these experiments were standardized by calculating the relative response to inoculation (RI) in each single inoculation trial as:

$\mathrm{RI}=\left(\mathrm{P}_{\mathrm{i}}-\mathrm{P}_{\mathrm{c}}\right) / \mathrm{P}_{\mathrm{c}} * 100$

where $P_{\mathrm{i}}$ represents the performance of inoculated plants and $P_{\mathrm{c}}$ represents that of non-inoculated control plants for the variable considered in an experiment. The RI values used in the two analyses were the average of the replicates of each inoculation treatments. In the HIA-related experiments, 343 RI data points were generated, and the CArelated experiments yielded 205 RI data points.

The CA- and HIA-related data sets were examined, seeking a possible relationship between soil properties and the functionality of AM fungal strains, as expressed by RI, in the different CA soils (Table 4) and HIA soils (Table 5). These two groups of data (CA- and HIA-related) were analyzed separately. Means of plant response to inoculation with different AM fungal strains in CA or HIA soils used constituted the response data sets, and corresponding soil fertility descriptors, $\mathrm{pH}$ and levels of $\mathrm{P}, \mathrm{K}, \mathrm{Ca}, \mathrm{Mg}$, and $\mathrm{OM}$, constituted the explanatory data sets. Soil type names were used as labels for each line (i.e., as objects) in both data sets, which were subjected to canonical correspondence analysis (CCA). The CCA were conducted using 1,000 runs in PC-ORD v. 4.34. Relative increments in plant performance in response to inoculation were normalized by transformation into classes $(<-30 \%,-30 \%$ to $-5 \%,-5 \%$ to $5 \%, 5 \%$ to $20 \%, 20 \%$ to $40 \%, 40 \%$ to $80 \%, 80 \%$ to $100 \%$, 


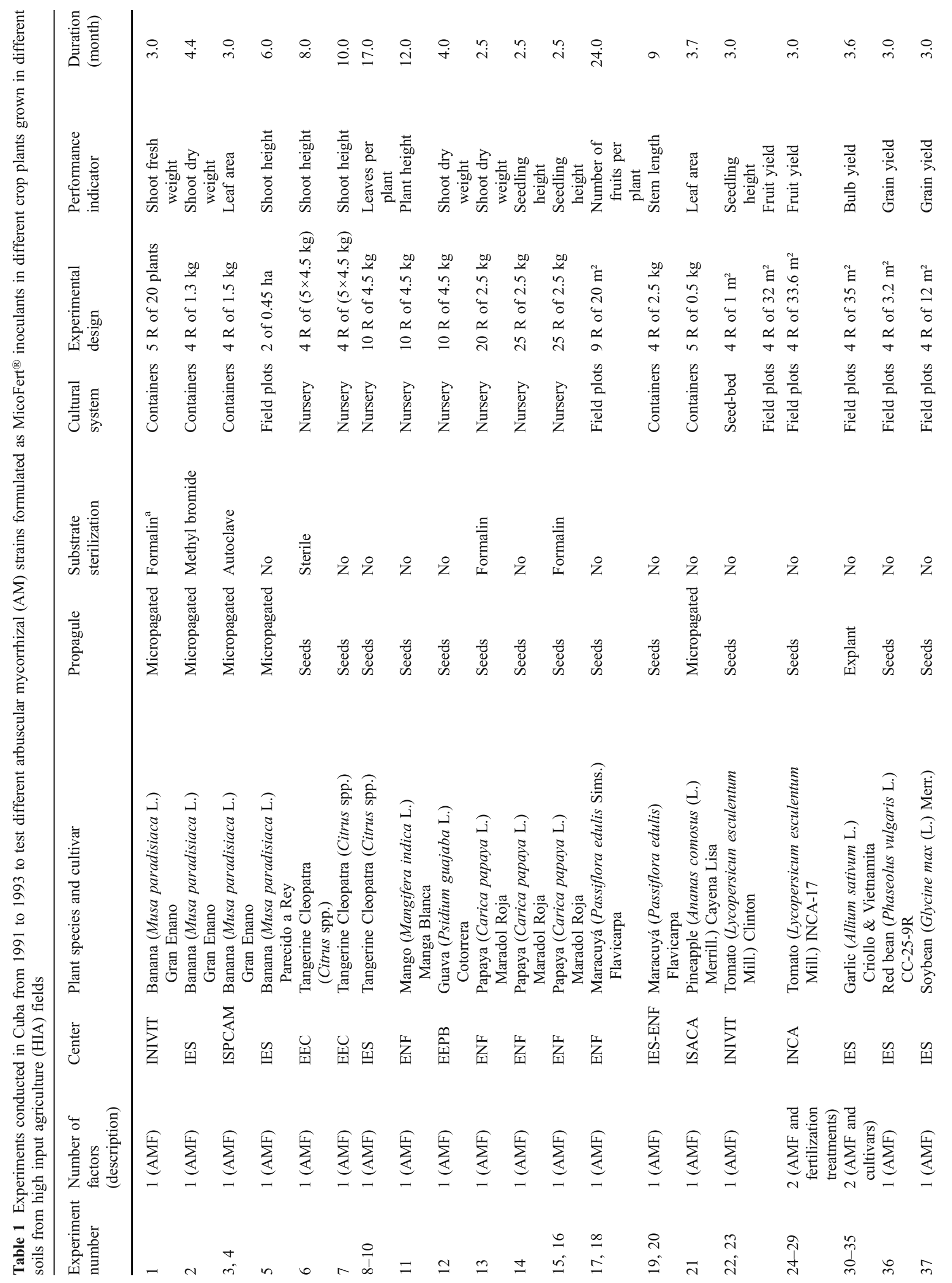




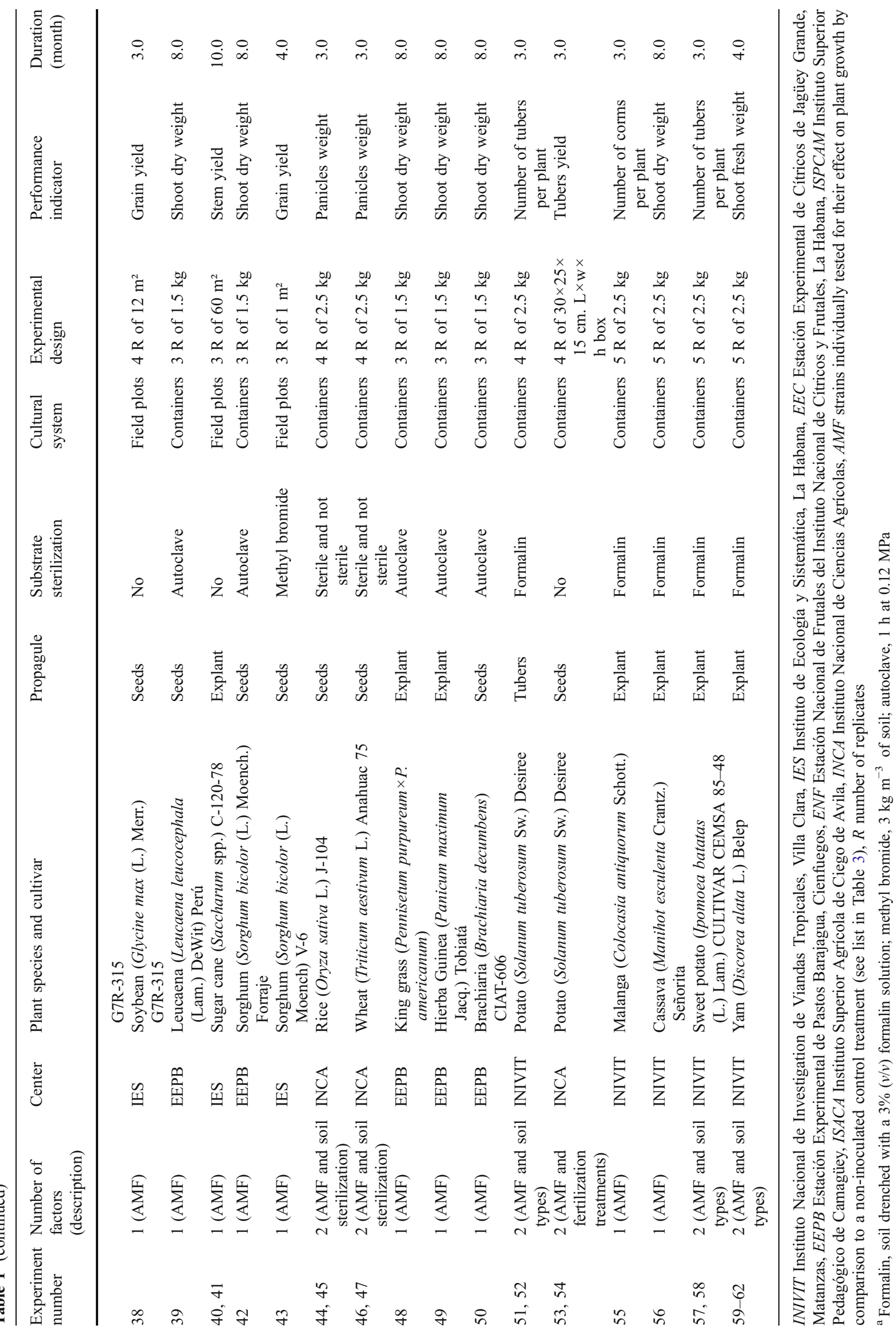


Table 2 Experiments conducted in Cuba from 1991 to 1993 to test different arbuscular mycorrhizal (AM) strains formulated as MicoFert ${ }^{\circledR}$ inoculants in coffee plants grown in different coffee plantation soils (CA)

\begin{tabular}{|c|c|c|c|c|c|}
\hline Case & Number of factors (description) & Field site & Cultivar & Cultural system & Experimental design \\
\hline $1-6$ & 2 (AMF and $\mathrm{VC})$ & Jibacoa & Catuaí Amarillo & Bags & $4 \mathrm{R}$ of $1 \mathrm{~m}^{2}$ \\
\hline $7-12$ & 3 (AMF, VC, and PSB) & Veguitas & Caturra Colombiano & Seedbed & $4 \mathrm{R}$ of $49 \mathrm{~m}^{2}$ \\
\hline 13 & $2(\mathrm{AMF}$ and $\mathrm{VC})$ & Jibacoa & Caturra Colombiano & Bags & $4 \mathrm{R}$ of $100 \mathrm{~m}^{2}$ \\
\hline 14,15 & 3 (AMF, VC, and BNF) & Veguitas & Caturra Colombiano & Bags & $4 \mathrm{R}$ of $100 \mathrm{~m}^{2}$ \\
\hline 16,17 & 4 (AMF, VC, BNF, and PSB) & Veguitas & Caturra Colombiano & Bags & $4 \mathrm{R}$ of $100 \mathrm{~m}^{2}$ \\
\hline $18-21$ & $1(\mathrm{AMF})$ & La Villa & Caturra Colombiano & Bags & $4 \mathrm{R}$ of $100 \mathrm{~m}^{2}$ \\
\hline $22-25$ & 2 (AMF, and $\mathrm{P}$ fertilization) & Bachiplán & Catuaí Amarillo & Bags & $4 \mathrm{R}$ of $100 \mathrm{~m}^{2}$ \\
\hline 26,27 & 2 (AMF and organic ammendment) & Cancán & Catuaí Amarillo & Bags & $4 \mathrm{R}$ of $100 \mathrm{~m}^{2}$ \\
\hline 28,29 & $2(\mathrm{AMF}$ and $\mathrm{VC})$ & Santiago & Catuaí Amarillo & Bags & $4 \mathrm{R}$ of $100 \mathrm{~m}^{2}$ \\
\hline $30-32$ & $1(\mathrm{AMF})$ & Tomatera & Catuaí Amarillo & Bags & $4 \mathrm{R}$ of $100 \mathrm{~m}^{2}$ \\
\hline $33-36$ & 3 (AMF, VC, BNF) & Tope de Collantes & Catuaí Amarillo & Bags & $4 \mathrm{R}$ of $100 \mathrm{~m}^{2}$ \\
\hline 37,38 & 3 (AMF, PSB, and BNF) & Tope de Collantes & Catuaí Amarillo & Bags & $4 \mathrm{R}$ of $100 \mathrm{~m}^{2}$ \\
\hline 39,40 & 2 (AMF, PSB) & Tope de Collantes & Catuaí Amarillo & Seedbed & $4 \mathrm{R}$ of $49 \mathrm{~m}^{2}$ \\
\hline 41,42 & $2(\mathrm{AMF}$ and $\mathrm{PSB})$ & Topes Collantes & Catuaí Amarillo & Seedbed & $4 \mathrm{R}$ of $49 \mathrm{~m}^{2}$ \\
\hline $43-46$ & 3 (AMF, VC, and PSB) & Cancán & Catuaí Amarillo & Seedbed & $4 \mathrm{R}$ of $49 \mathrm{~m}^{2}$ \\
\hline 47,48 & $2(\mathrm{AMF}$ and $\mathrm{VC})$ & Jibacoa & Catuaí Amarillo & Seedbed & $4 \mathrm{R}$ of $49 \mathrm{~m}^{2}$ \\
\hline $49-52$ & 3 (AMF, VC, and BNF) & Santiago & Catuaí Amarillo & Seedbed & $4 \mathrm{R}$ of $49 \mathrm{~m}^{2}$ \\
\hline $53-56$ & 3 (AMF, VC, BNF) & Tercer Frente & Catuaí Amarillo & Bags & $4 \mathrm{R}$ of $100 \mathrm{~m}^{2}$ \\
\hline $57-60$ & 3 (AMF, VC, BNF) & Veguitas & Catuaí Amarillo & Seedbed & $4 \mathrm{R}$ of $49 \mathrm{~m}^{2}$ \\
\hline $61-64$ & 3 (AMF, VC, PSB) & Veguitas & Catuaí Amarillo & Seedbed & $4 \mathrm{R}$ of $49 \mathrm{~m}^{2}$ \\
\hline $65-68$ & 3 (AMF, VC, BNF) & Jibacoa & Catuaí Amarillo & Seedbed & $4 \mathrm{R}$ of $49 \mathrm{~m}^{2}$ \\
\hline
\end{tabular}

Seeds were used as propagules, the soil was non-sterile, plants were grown for 7 months, and all experiments were conducted by EICVC, Estación de Investigationes del Café Jibacoa at different field sites. The performance indicator was leaf area, except for one experiment where shoot dry weight was used

$A M F$ strains individually formulated as MicoFert ${ }^{\circledR}$ and tested for their effect on plant growth by comparison to a non-inoculated control treatment and, in some cases, with a mix of native strains (see list in Table 3), $V C$ vermicompost from coffee fruit residues, PSB P solubilizing bacteria, $B N F$ $\mathrm{N}$-fixing bacteria, $R$ number of replicates used

and $>100 \%$ ) before subjecting the data to CCA (Fig. 1). The use of CCA was dictated by the non-linear response of AM fungi to environmental conditions (Bethlenfalvay et al. 1983; Hamel et al. 1997) and the wide ranges of gradients in soil fertility descriptors resulting from the use of soil with contrasting properties (Ter Braak 1986; Legendre and Legendre 1998, p. 600; Ramette 2007).

The relationship between pairs of soil fertility descriptors within each of the CA and HIA soil groups were assessed by regression analysis using JMP v.3.2.6 (SAS Institute, Cary, USA), as a mean to describe nutrient balance in CA and HIA soils.

\section{Soil analysis}

The $\mathrm{P}$ availability of $\mathrm{CA}$ soils was tested using the Bray extracting solution (Bray and Kurtz 1945) and that in HIA soils using the Olsen extracting solution (Olsen et al. 1954). Soil $\mathrm{pH}$ in water was determined using a $\mathrm{pH}$ meter. Soil OM content was determined by the Walkley-Black method
(Jackson 1962). Amounts of exchangeable $\mathrm{K}, \mathrm{Ca}$ and $\mathrm{Mg}$ were determined using $1 \mathrm{M}$ ammonium acetate at $\mathrm{pH} 7$ (Jackson 1962). Soil analyses were conducted on samples taken from the top 0-20 cm soil layer at all locations.

At all sites where CA soils were taken except one, a pit was dug, the soil profile was described and the soil was classified according to the FAO-UNESCO system (FAO, ISRIC and ISSS 1998). Soils at other sites had already been described and existing descriptions were used.

$\mathrm{AM}$ inoculum and inoculation

The AM fungal strains used (Table 3) were formulated into MicoFert $^{\circledR}$ (Instituto de Ecología y Sistemática [IES], La Habana, Cuba) inoculants. MicoFert ${ }^{\mathbb{R}}$ contains a mixture of AM fungi-colonized soil and colonized root fragments, which are produced on Sorghum (Sorghum bicolor (L.) Moench) inoculated with IES-certified AM fungal strains and grown for 90 days in a 3:1 ( v/v) mixture of soil/cachaza, which is an organic amendment from sugarcane residues. 
Table 3 Arbuscular mycorrhizal fungal strains used in the experiments conducted in soils with history of high input agriculture or in soils from coffee plantations with their abbreviation and origin

\begin{tabular}{|c|c|c|c|c|c|}
\hline Abbreviation & Name & $\begin{array}{l}\text { IES-Nr } \\
\text { accession }\end{array}$ & Origin & Used in HIA cases (number) & $\begin{array}{l}\text { Used in CA } \\
\text { cases (number) }\end{array}$ \\
\hline Aca & Acaulospora scrobiculata Trappe & IES-10 & $\begin{array}{l}\text { CIAT, Cali, Colombia } \\
\text { Collection E. } \\
\text { Sieverding }\end{array}$ & $\begin{array}{l}1-4,7,38-39,42-43 \\
48,56-57\end{array}$ & $14-17,28-48$ \\
\hline Agg & $\begin{array}{l}\text { Glomus aggregatum N.C. Schenck } \\
\& \text { A. Schüßler }\end{array}$ & IES-4 & $\begin{array}{l}\text { W. Escambray, Villa } \\
\text { Clara, Cuba }\end{array}$ & $7-8,12-21,37,44-47,49-55$ & \\
\hline $\mathrm{cl}-1$ & Glomus clarum-like & IES-13 & $\begin{array}{l}\text { UNAM, México, } \\
\text { Collection S. Palacios }\end{array}$ & $8,16-19$ & \\
\hline Div & $\begin{array}{l}\text { Diversispora spurca (C.M. Pfeiff., C. } \\
\text { Walker \& Bloss) C. Walker \& A. Schüßler }\end{array}$ & IES-3 & $\begin{array}{l}\text { W. Escambray, Villa } \\
\text { Clara, Cuba }\end{array}$ & $\begin{array}{l}1-6,8,12-14,16-21,37 \\
40-41,44-47,49-55,58-62\end{array}$ & $28-46$ \\
\hline et- $1_{1}$ & Glomus etunicatum-like & IES-6 & $\begin{array}{l}\text { Puerta de Golpe, Pinar } \\
\text { del Rio, Cuba }\end{array}$ & $\begin{array}{l}8,16-21,37,44-47 \\
49-55,58,62\end{array}$ & \\
\hline et $-\mathrm{l}_{2}$ & Glomus etunicatum-like & IES-7 & $\begin{array}{l}\text { W. Escambray, Villa } \\
\text { Clara, Cuba }\end{array}$ & $\begin{array}{l}8,16-21,37,46-47 \\
49-55,58-62\end{array}$ & $57-68$ \\
\hline fa-1 & Glomus fasciculatum-like & IES-1 & $\begin{array}{l}\text { Turin, Italy. LPA-7 in } \\
\text { INRA, Dijon, France }\end{array}$ & $1-8,10-14,16-62$ & $\begin{array}{l}1-12,18-27 \\
49-68\end{array}$ \\
\hline int $_{1}$ & $\begin{array}{l}\text { Glomus intraradices N.C. Schenck } \\
\text { \& G.S. Sm. }\end{array}$ & IES-9 & $\begin{array}{l}\text { UNAM, México, } \\
\text { Collection S. Palacios }\end{array}$ & $\begin{array}{l}12-21,37-39,42-49 \\
56-57\end{array}$ & \\
\hline int $_{2}$ & $\begin{array}{l}\text { Glomus intraradices N.C. Schenck } \\
\text { \& G.S. Sm }\end{array}$ & IES-12 & $\begin{array}{l}\text { UNAM, México, } \\
\text { Collection S. Palacios }\end{array}$ & $5-6,16-19$ & \\
\hline Man & $\begin{array}{l}\text { Glomus manihotis R.H. Howeler, } \\
\text { Sieverd. \& N.C. Schenck }\end{array}$ & IES-2 & $\begin{array}{l}\text { CIAT, Cali, Colombia } \\
\text { Collection E. } \\
\text { Sieverding }\end{array}$ & $1-4,7-14,16-62$ & $\begin{array}{l}13,26-46 \\
49-56\end{array}$ \\
\hline mo- $1_{2}$ & Glomus mosseae-like & IES-14 & $\begin{array}{l}\text { Los Pinos, Ciudad de } \\
\text { La Habana, Cuba }\end{array}$ & $8,16-19$ & \\
\hline Mos & $\begin{array}{l}\text { Glomus mosseae (T.H. Nicolson \& Gerd.) } \\
\text { Gerd. \& Trappe }\end{array}$ & IES-8 & $\begin{array}{l}\text { Est. Nac. Frutales, Gïra } \\
\text { de Melena, Cuba }\end{array}$ & $\begin{array}{l}1-4,7-8,10-11,16-19, \\
22-27,37-39,42-45,48-57\end{array}$ & $\begin{array}{l}1-13,18-27 \\
49-52,57-68\end{array}$ \\
\hline mos-1 & Glomus mosseae-like & IES-5 & $\begin{array}{l}\text { W. Escambray, Villa } \\
\text { Clara, Cuba }\end{array}$ & $\begin{array}{l}3,12-14,16-19,37 \\
49-55,58-62\end{array}$ & $1-12,18-25$ \\
\hline NSC & Native strains concentrate & $\mathrm{n} / \mathrm{a}$ & $\mathrm{n} / \mathrm{a}$ & & $47-48,53-56$ \\
\hline Occ & $\begin{array}{l}\text { Paraglomus occultum (C. Waker) J.B. } \\
\text { Morton \& D. Redecker }\end{array}$ & IES-11 & $\begin{array}{l}\text { CIAT, Cali, Colombia } \\
\text { Collection E. } \\
\text { Sieverding }\end{array}$ & $\begin{array}{l}7,16-19,38-39,42-43 \\
48,56-57\end{array}$ & $14-17,47-48$ \\
\hline
\end{tabular}

$n / a$ not applicable

The rate of inoculant applied to the experimental plants followed the manufacturer recommendation, i.e., rates of $5 \mathrm{~cm}^{3}$ plant $^{-1}$ of MicoFert ${ }^{\circledR}$ were used to inoculate seeds smaller than $2 \mathrm{~cm}$ and $10 \mathrm{~cm}^{3}$ plant $^{-1}$ was used for larger seeds and micro-propagated plants. The inoculants were placed in the planting holes. Rates of 0.5 to $1.0 \mathrm{dm}^{3} \mathrm{~m}^{-2}$ of MicoFert ${ }^{\circledR}$ were used in seedbeds.

\section{Results}

HIA and CA soils comparison

A range of plant response to inoculation varying from positive to negative were obtained in both HIA and CA soils (Fig. 1).

Examination of the chemical analyses of HIA and CA soils revealed that these soils differed most in their level of OM (Tables 4 and 5). Note that the extracting solution used for Bray index determination extracts larger proportions of $\mathrm{P}$ from soils than the Olsen extracting solution (Bationo et al. 1991). The relationships between pairs of soil variables were all positive and relatively strong in CA soils, but weak and sometimes negative in HIA soils (Fig. 2), suggesting the alteration of soils' chemical equilibrium by HIA management.

Soil influences on plant response to inoculation

Canonical correspondence analysis (CCA) revealed relationships between plant response to inoculation with different $\mathrm{AM}$ fungal strains and soil chemical properties in CA $(P=0.001)$, but not in HIA $(P=0.413)$ systems (Fig. 3). Perpendicular projections of plant response to inoculation with the various AM fungal strains on vectors describing soil fertility descriptors indicates at which relative levels of fertility AM fungal strains function better. In CA soils fa-l and et- $\mathrm{l}_{2}$ produced their best response in 
Table 4 Properties of soils from high input agriculture (HIA) fields
CC Calcaric Cambisol, CCE

Chromic, Eutric Cambisol, $C E$

Eutric Cambisol, FFR Ferric,

Rodic Ferralsol, FR Rodic

Ferralsol, GA Alumic Gleysol

${ }^{\mathrm{a}}$ The Olsen solution is used in the analysis of HIA extract soil P less thoroughly than the Bray solution used for CA soils (Bationo et al. 1991)

Table 5 Properties of soils from coffee (CA) plantations
$A C$ Chromic Alisol, ACCE

Chromic, Eutric Alluvial

Cambisol, $C C$ Calcaric

Cambisol, CCE Chromic, Eutric

Cambisol, FR Rodic Ferralsol,

NRXE Rodic-Xantic, Eutric

Nitisol

${ }^{\mathrm{a}}$ The Bray solution used in the analysis of CA extract soil $\mathrm{P}$ more thoroughly than the Olsen solution used for HIA soils (Bationo et al. 1991)

\begin{tabular}{|c|c|c|c|c|c|c|c|}
\hline Experiment number & Soil type & $\mathrm{pH}$ & $\mathrm{OM}$ & $\mathrm{P}^{\mathrm{a}}$ & \multicolumn{2}{|c|}{$\left(\mathrm{cmol} \mathrm{kg}^{-1}\right)$} & $\mathrm{Mg}$ \\
\hline $1,22-25,57-58$ & $\mathrm{CC}$ & 6.9 & 1.46 & 8.5 & 59.7 & 48.0 & 4.32 \\
\hline 12 & $\mathrm{CC}$ & 6.5 & nd & 73.9 & 89.1 & 26.9 & 10.53 \\
\hline $42-43$ & $\mathrm{CC}$ & 5.5 & 3.48 & 16.2 & 74.8 & 0.4 & 0.06 \\
\hline $19-20$ & $\mathrm{CCE}$ & 7.7 & 1.48 & 12.0 & 134.7 & nd & nd \\
\hline $41,44,50-52$ & $\mathrm{CE}$ & 5.2 & nd & 16.8 & 17.5 & nd & nd \\
\hline $3-4$ & FFR & 6.7 & 1.53 & 51.0 & 15.1 & 0.3 & 0.23 \\
\hline 21 & FFR & 6.7 & 1.53 & 22.3 & 13.0 & 0.3 & 1.41 \\
\hline $14-16,38$ & FR & 7.2 & nd & 48.0 & 19.9 & 31.8 & 6.58 \\
\hline 6 & FR & 7.1 & 2.43 & 121.9 & 74.8 & 16.5 & 2.55 \\
\hline 7,11 & FR & 6.8 & 2.80 & 97.5 & 71.8 & 17.6 & 2.65 \\
\hline $55-56$ & FR & 6.8 & 2.40 & 75.0 & 59.8 & 11.9 & 0.40 \\
\hline $53-54,59-62$ & FR & 6.7 & 1.83 & 48.1 & 42.8 & 9.6 & 0.46 \\
\hline $8-10,35-37$ & FR & 6.5 & nd & 19.0 & nd & nd & nd \\
\hline 2 & FR & 6.1 & nd & 65.6 & nd & nd & nd \\
\hline $32-34$ & FR & 6.1 & nd & 130.7 & 82.8 & nd & nd \\
\hline $26-31$ & FR & 6.0 & 2.11 & 234.0 & 31.9 & 8.5 & 1.62 \\
\hline 45 & FR & 6.0 & nd & 125.9 & nd & nd & nd \\
\hline $13,17-18$ & FR & 5.9 & nd & 74.3 & nd & nd & nd \\
\hline 39 & FR & 5.8 & 2.17 & 289.0 & 69.8 & 9.9 & 1.49 \\
\hline 5 & FR & 5.7 & nd & 36.4 & 91.3 & 10.0 & 2.41 \\
\hline 40 & FR & 5.1 & 2.96 & 3.7 & 21.9 & 4.9 & 4.10 \\
\hline $46-49$ & GA & 4.9 & 2.20 & 25.0 & 10.0 & 12.1 & 1.00 \\
\hline Average & & 6.3 & 2.18 & 72.5 & 54.5 & 13.9 & 2.65 \\
\hline $\mathrm{CV}$ & & 0.12 & 0.29 & 1.01 & 0.64 & 0.94 & 1.06 \\
\hline Experiment number & Soil type & $\mathrm{pH}$ & $\mathrm{OM}$ & $\mathrm{P}$ & $\begin{array}{l}\mathrm{K} \\
(\mathrm{cmol})\end{array}$ & $\mathrm{Ca}$ & $\mathrm{Mg}$ \\
\hline $1-12$ & ACCE & 5.2 & 3.0 & 44.8 & 32.0 & 8.0 & 2.4 \\
\hline 13 & ACCE & 5.7 & 3.8 & 26.9 & 19.2 & 12.8 & 1.4 \\
\hline $14-17$ & ACCE & 5.8 & 3.0 & 30.6 & 16.4 & 5.1 & 1.5 \\
\hline $18-21$ & ACCE & 5.8 & 3.5 & 13.9 & 27.5 & 8.6 & 1.5 \\
\hline $22-25$ & ACCE & 5.8 & 3.0 & 30.6 & 16.4 & 5.1 & 1.5 \\
\hline $26-27$ & $\mathrm{CCE}$ & 6.4 & 4.1 & 175.0 & 79.8 & 11.2 & 1.3 \\
\hline $28-29$ & $\mathrm{CCE}$ & 7.1 & 3.8 & 175.0 & 59.8 & 14.0 & 1.4 \\
\hline $30-32$ & NRXE & 4.9 & 1.0 & 12.0 & 39.9 & 7.0 & 1.6 \\
\hline $33-36$ & $\mathrm{AC}$ & 4.9 & 1.2 & 11.8 & 18.5 & 1.4 & 1.4 \\
\hline $37-38$ & $\mathrm{AC}$ & 4.8 & 1.5 & 12.7 & 10.4 & 1.5 & 1.1 \\
\hline $39-40$ & FR & 6.8 & 3.4 & 62.0 & 49.7 & 8.4 & 1.2 \\
\hline $41-42$ & FR & 6.8 & 3.4 & 228.1 & 49.7 & 8.4 & 1.2 \\
\hline $43-46$ & FR & 7.1 & 3.8 & 70.3 & 59.6 & 7.8 & 1.4 \\
\hline $47-48$ & FR & 5.8 & 3.0 & 56.8 & 37.6 & 5.2 & 1.5 \\
\hline $49-52$ & $\mathrm{CC}$ & 6.8 & 4.1 & 169.8 & 79.4 & 23.5 & 1.3 \\
\hline $53-56$ & $\mathrm{CC}$ & 7.3 & 3.8 & 248.9 & 112.1 & 32.0 & 7.9 \\
\hline $57-60$ & $\mathrm{CC}$ & 6.0 & 3.0 & 116.6 & 53.3 & 14.3 & 2.4 \\
\hline $61-64$ & $\mathrm{CC}$ & 6.0 & 3.0 & 105.7 & 53.3 & 14.3 & 2.4 \\
\hline $65-68$ & $\mathrm{CC}$ & 6.6 & 3.5 & 101.3 & 48.6 & 15.3 & 1.5 \\
\hline Average & & 6.08 & 3.10 & 89.09 & 45.43 & 10.73 & 1.89 \\
\hline $\mathrm{CV}$ & & 0.13 & 0.29 & 0.84 & 0.56 & 0.67 & 0.78 \\
\hline
\end{tabular}



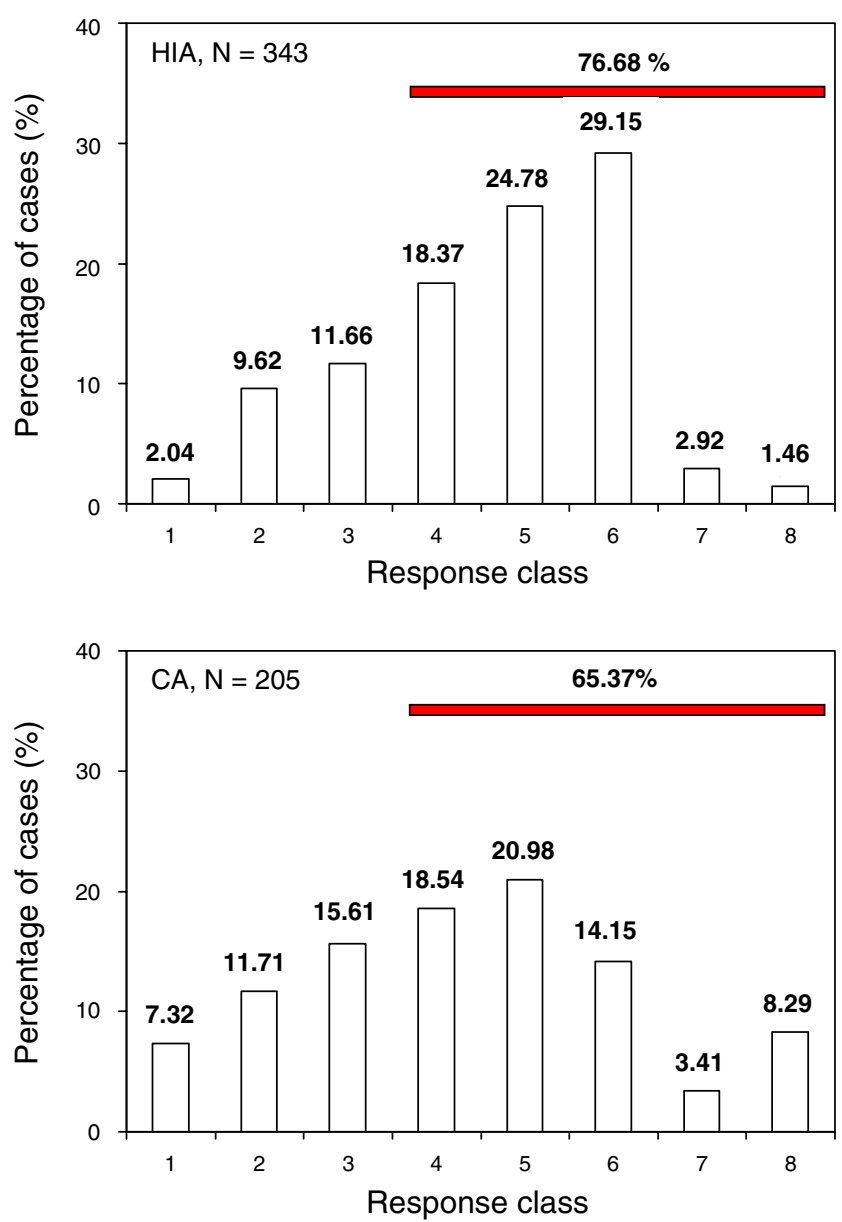

Fig. 1 Percentage of inoculation cases falling in each of eight classes of plant growth responses to AM inoculation observed in the 68 and 62 inoculation experiments conducted in coffee plantation soils (CA) or soils with a history of high input agriculture (HIA), respectively. Growth response less than $-30 \%$, in the ranges of $-30 \%$ to $-5 \%,-5 \%$ to $5 \%, 5 \%$ to $20 \%, 20 \%$ to $40 \%, 40 \%$ to $80 \%, 80 \%$ to $100 \%$, and above $100 \%$, were classified as classes $1,2,3,4,5,6,7$, and 8, respectively. The percentage of cases where inoculation produced a positive growth response is given on the line drawn above classes 4 8 in each of the HIA- and CA-related panel

soils with relatively high levels of available $\mathrm{P}$; mos and man, in soils with medium $\mathrm{P}$ availability; and occ, in soils with relatively low P availability (Fig. 3). Because nutrient levels were all positively correlated in CA soils, it is also true that fa-l and et- $\mathrm{l}_{2}$ produced better responses in coffee plants grown in soils generally rich in nutrients and $\mathrm{OM}$, in contrast to occ, which produced better responses in relatively poor soils (Fig. 3). Native strains (NSC) functioned best in relatively rich soils.

CA soils belonging to the same taxonomic group appeared in clusters when plotted on the ordination graph (Fig. 3). This clustering suggests that the response to AM inoculation depends on the interaction between the AM strain and the properties of the soil where it is inoculated,

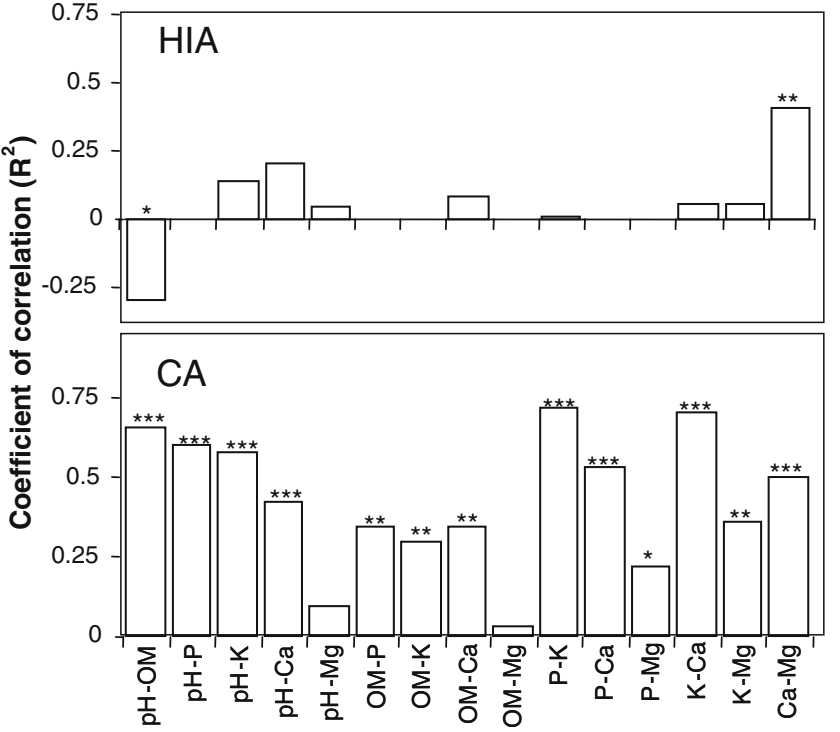

Fig. 2 Coefficients of pairwise correlation $\left(R^{2}\right)$ between soil fertility descriptors with their level of significance, obtained from the analysis of soils from high input agriculture (HIA) and coffee plantation (CA). Single asterisk, double asterisk, and triple asterisk indicate that the correlation is significant at $\alpha=0.05,0.01$, and 0.001 , respectively

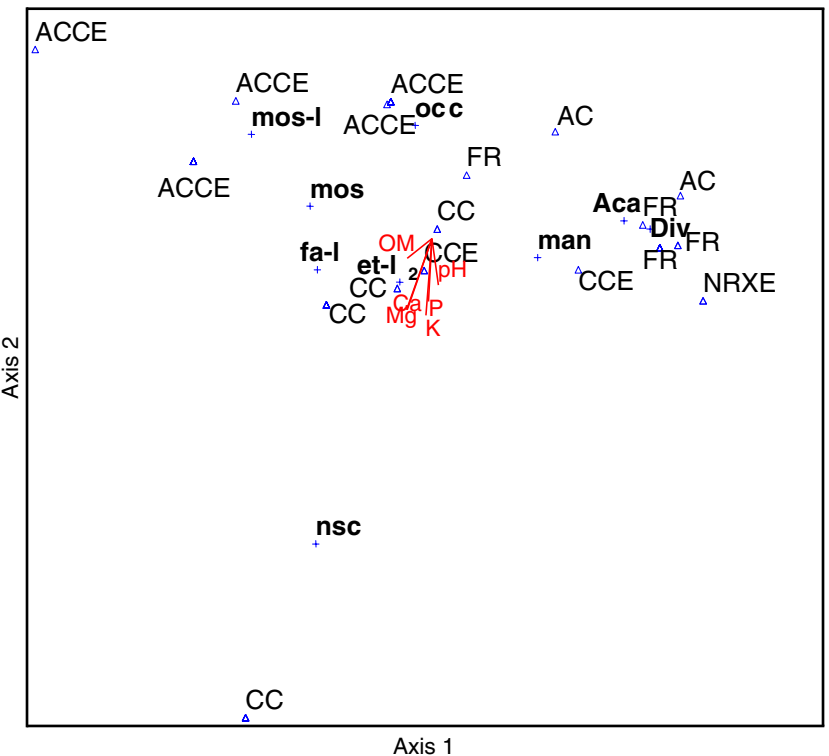

Fig. 3 Ordinations of the relationships between soil fertility descriptors and relative coffee plant growth increment following inoculation with different AM fungal strains, from canonical correspondence analysis (CCA) $(P=0.001$ for axes 1 , Monte Carlo test with 999 iterations; plant response-soil properties correlation $=0.888,0.873$, and 0.643 for axes 1,2, and 3, respectively). The objects (experimental soils) of these analyses are labelled with their taxonomic (FAO) names in the ordination biplot. $O M$ soil organic matter, $A C$ Chromic Alisol, ACCE Chromic, Eutric Alluvial Cambisol, $C C$ Calcaric Cambisol, CCE Chromic, Eutric Cambisol, CE Eutric Cambisol, FFR Ferric, Rodic Ferralsol, FR Rodic Ferralsol, GA Alumic Gleysol, NRXE Rodic-Xantic, Eutric Nitisol. See Table 3 for abbreviations of AM fungal strains 
and this relationship can be inferred from the soil type, at least in Cuban coffee plant production. In CA, strain mo-l, mos and occ appear to stimulate better coffee growth in Chromic, Eutric Allivual Cambisol (ACCE), Aca and Div in Rodic Ferrasols (FR, FRR) and in Chromic Alisols (AC), fa-l, et $\mathrm{l}_{2}$ and NSC in Calcaric Cambisol, and man in Eutric Chromic Cambisols (Fig. 3).

\section{Discussion}

Early studies have shown that plant response to inoculation varied in different soils (Young et al. 1986; Hamel et al. 1997; Zeuske and Weber 2000; Schreiner 2007) and until now, this lack of consistency has hindered the efficient use of AM inoculants in plant production. Our results suggest that AM strains must not only be highly effective, they must also be able to function in the soil environment where they are introduced. Selecting strains based on target soil properties may be the key to consistency in the effect of $\mathrm{AM}$ inoculants.

In the more pristine CA soils, the very good relationships between plant response to different AM strains and soil taxa suggests the possibility of choosing AM fungal strains based on soil taxonomic group. This would be very convenient, as soils in agricultural areas have often been described. The soil taxonomic group at a given location is usually known and the appropriate strain among a few strains with high plant growth enhancement potential could be chosen based on this available information, which is simple, rapid and cost-effective. This strategy would be appropriate in regions with relatively low input agriculture such as the Canadian prairie, a major wheat and pulse growing area, where conservation tillage is the common practice and fertilizers have been used with parsimony (Fixen 2006) because water availability is usually the factor limiting yields.

The relationship between plant response to AM strains and soil type was very clear in CA. The levels of the different soil fertility descriptors were well correlated and soils showed a gradient of general fertility ranging from low to high. Relationships were more complex in HIA soils, where correlations between the soil fertility descriptors were poor, in particular in those involving soil $\mathrm{P}$ or OM.

Not only nutrient level, but also nutrient balance is an important factor influencing AM symbiotic development and function (Liu et al. 2000; Fitzsimons et al. 2008). Nutrient imbalance may alter the function of indigenous AM fungal strains. Soils with altered nutrient balance may benefit from the introduction of an adapted AM strains. Plant response to inoculation was not less frequent in HIA than in CA soils (Fig. 1), although they were richer in P.
It is true that plant dependence on the AM symbiosis generally decreases with increasing soil fertility (Smith and Read 1997), but a negative impact of soil fertility cannot be assumed to occur. Available $\mathrm{N}$ and $\mathrm{P}$ scarcity, as well as abundance, may limit AM fungal development (Bethlenfalvay et al. 1983; Chulan and Ragu 1986; Liu et al. 2000; Treseder and Allen 2002). Soil properties influence functionality in AM fungi (Frey and Ellis 1997; Hamel et al. 1997; Carrenho et al. 2007; Arines et al. 1988; Warnock et al. 2007; Mechri et al. 2008). Different AM strains have different ability to function in different soil environments as shown by different AM fungal community composition (Corkidi et al. 2002; He et al. 2004, Fitzsimons et al. 2008), development (Abbott and Robson 1991), sporulation (Baum et al. 2002), and function (Karasawa et al. 2001) in different soils.

It is very important to clarify the suitability of AM fungal isolates employed in connection with soil fertility, as shown here and as pointed out by Zeuske and Weber (2000). It is also important to recognize that the pattern of AM fungal strains proliferation (Hijri et al. 2006; Chao et al. 2010), development and influence on plant growth (Bethlenfalvay et al. 1983) can be unimodal rather than linear, along large soil environmental gradients of multiple factors. The fitness of AM fungi may be limited to a set of specific environmental conditions beyond which they cannot function.

Consistency of response to inoculation with selected AM fungal strains is a prerequisite to adoption of $\mathrm{AM}$ inoculation practices in plant production. Thus, it may be important to consider strain-soil compatibility as the AM strains must be introduced in soil environments where their basic requirements are met and where they can function well. It may also be important to consider soil nutrient balance. It is true that the genotype of crop plants may also influence the outcome of AM associations (Klironomos 2003) and ideally, the selection of AM fungal strains should be based on both the target soil and the crop. In HIA systems, the correlation between crop response to AM strains and soil properties could have been confounded by the use of different crop plants. Lack of correlation might also be attributable to soil nutrient imbalance complicating interactions.

Highly effective strains perform generally well on a wide range of crops, and AM inoculation based only on soil type has been successful in Cuba (Rivera et al. 2007).

\section{Conclusions}

The reliability of highly effective AM fungal strains seemingly depends on their ability to function under the soil conditions where they are introduced. The choice of effective AM fungal strains based on soil properties may 
well be the corner stone for the development of effective use of AM inoculants in plant production systems.

Acknowledgement Collaboration between the two first authors was supported by a grant from the Inter-American Institute for Global Change Research (IAI) CRN, which is supported by the US National Science Foundation (Grant GEO-04523250). RA Herrera-Peraza passed away during the preparation of this article. Most of the HIA data was generated by late RL Ferrer.

Open Access This article is distributed under the terms of the Creative Commons Attribution Noncommercial License which permits any noncommercial use, distribution, and reproduction in any medium, provided the original author(s) and source are credited.

\section{References}

Abbott LK, Robson AD (1991) Factors influencing the occurrence of vesicular-arbuscular mycorrhizas. Agric Ecosyst Environ $35: 121-150$

Arines J, Vilarino A, Sainz M (1988) 'Fine' and 'coarse' mycorrhizal fungi on red clover plants in acid soils: root colonization and plant responses. Plant Soil 111:135-145

Bationo A, Baethgen WE, Christianson CB, Mokwunye AU (1991) Comparison of five soil testing methods to establish phosphorus sufficiency levels in soil fertilized with water-soluble and sparingly soluble-P source. Fertil Res 28:271-279

Baum C, Weih M, Verwijst T, Makeschin F (2002) The effects of nitrogen fertilization and soil properties on mycorrhizal formation of Salis viminalis. For Ecol Manag 160:35-43

Bethlenfalvay GJ, Bayne HG, Pacovsky RS (1983) Parasitic and mutualistic associations between a mycorrhizal fungus and soybean: the effect of phosphorus on host plant-endophyte interactions. Physiol Plant 57:543-548

Bray RH, Kurtz LT (1945) Determination of total organic and available forms of phosphorus in soils. Soil Sci 59:39-45

Brundrett MC (2009) Mycorrhizal associations and other means of nutrition of vascular plants: understanding the global diversity of host plants by resolving conflicting information and developing reliable means of diagnosis. Plant Soil 320:1-41

Carrenho R, Trufem SFB, Bononi VLR, Silva ES (2007) The effect of different soil properties on arbuscular mycorrhizal colonization of peanuts, sorghum and maize. Acta Bot Bras 21:723-730

Chao Y, Hamel C, Schellenberg MP, Perez JC, Berbara, RL (2010) Diversity and functionality of arbuscular mycorrhizal fungi in three plant communities found within semiarid Grassland National Park, Canada. Mycorrhiza (in press) 09-2009

Chulan A, Ragu P (1986) Growth response of Theobroma cacao L. seedlings to inoculation with vesicular-arbuscular mycorrhizal fungi. Plant Soil 96:279-285

Corkidi L, Rowland DL, Johnson NC, Allen EB (2002) Nitrogen fertilization alters the functioning of arbuscular mycorrhizas at two semiarid grasslands. Plant Soil 240:299-310

FAO, ISSS, ISRIC (1998) World reference base for soil resources. ISSS-ISRIC-FAO, Rome

Feddermann N, Finlay R, Boller T, Elfstrand M (2010) Functional diversity in arbuscular mycorrhiza - the role of gene expression, phosphorous nutrition and symbiotic efficiency. Fungal Ecol 3:1-8

Fernández, F (1999) Manejo de las asociaciones micorrízicas arbusculares sobre la producción de posturas de cafeto $(C$. arabica L. var. Catuaí) en algunos tipos de suelos. Dissertation, Universidad Agraria de La Habana, INCA
Fitzsimons MS, Miller RM, Jastrow JD (2008) Scale-dependent niche axes of arbuscular mycorrhizal fungi. Oecologia 158:117127

Fixen PE (2006) Soil test levels in North America. Better Crops 90: 4-7

Frey JE, Ellis JR (1997) Relationship of soil properties and soil amendments to response of Glomus intraradices and soybeans. Can J Bot 75:483-491

Gilbert N (2009) The disappearing nutrient. Nature 461:716-718

Gryndler M, Hrselová H, Cajthaml T, Havránková M, Rezáčová V, Gryndlerová H, Larsen J (2009) Influence of soil organic matter decomposition on arbuscular mycorrhizal fungi in terms of asymbiotic hyphal growth and root colonization. Mycorrhiza 19:255-266

Hamel C (2007) Extraradical arbuscular mycorrhizal mycelia: shadowy figures in the soil. In: Hamel C, Plenchette C (eds) Mycorrhizae in crop production: applying knowledge. Haworth, Binghampton, pp $1-36$

Hamel C, Dalpe Y, Lapierre C, Simard RR, Smith DL (1994) Composition of the vesicular-arbuscular mycorrhizal fungi population in an old meadow as affected by $\mathrm{pH}$, phosphorus and soil disturbance. Agric Ecosyst Environ 49:223-231

Hamel C, Dalpé Y, Furlan V, Parent S (1997) Indigenous populations of arbuscular mycorrhizal fungi and soil aggregate stability are major determinants of leek (Allium porrum L.) response to inoculation with Glomus intraradices Schenck \& Smith or Glomus versiforme (Karsten) Berch. Mycorrhiza 7:187-196

He X, Pen-Mouratov S, Steinberger Y (2004) Research note: spatial variation of AM fungal spore numbers under canopies of Acacia raddiana. Arid Land Res Manag 18:295-299

Helgason T, Fitter AH (2009) Natural selection and the evolutionary ecology of the arbuscular mycorrhizal fungi (Phylum Glomeromycota). J Exp Bot 60:2465-2480

Helgason T, Merryweather JW, Denison J, Wilson P, Young JPW, Fitter AH (2002) Selectivity and functional diversity in arbuscular mycorrhizas of co-occurring fungi and plants from a temperate deciduous woodland. J Ecol 90:371-384

Hijri I, Sýkorová Z, Oehl F, Ineichen K, Mäder P, Wiemken A, Redecker D (2006) Communities of arbuscular mycorrhizal fungi in arable soils are not necessarily low in diversity. Mol Ecol 15:2277-2289

Jackson ML (1962) Soil chemical analysis. Constable \& Co. Ltd., London

Johnson D, Leake JR, Read DJ (2005) Liming and nitrogen fertilization affects phosphatase activities, microbial biomass and mycorrhizal colonisation in upland grassland. Plant Soil 271:157-164

Karasawa T, Kasahara Y, Takebe M (2001) Variable response of growth and arbuscular mycorrhizal colonization of maize plants to preceding crops in various types of soils. Biol Fertil Soils $33: 286-293$

Klironomos JN (2003) Variation in plant response to native and exotic arbuscular mycorrhizal fungi. Ecology 84:2292-2301

Leake JR, Johnson D, Donnelly DP, Muckle GE, Boddy L, Read DJ (2004) Networks of power and influence: the role of mycorrhizal mycelium in controlling plant communities and agroecosystem functioning. Can J Bot 82:1016-1045

Legendre P, Legendre L (1998) Numerical ecology. Developments in environmental modelling 20. Elsevier, Amsterdam

Liu A, Hamel C, Hamilton RI, Smith DL (2000) Mycorrhizae formation and nutrient uptake of new corn (Zea mays L.) hybrids with extreme canopy and leaf architecture as influenced by soil $\mathrm{N}$ and P levels. Plant Soil 221:157-166

Mechri B, Mariem FB, Baham M, Elhadj SB, Hammami M (2008) Change in soil properties and the soil microbial community following land spreading of olive mill wasterwater affects olive 
trees key physiological parameters and the abundance of arbuscular mycorrhizal fungi. Soil Biol Biochem 40:152-161

Oehl F, Redecker D, Sieverding E (2005) Glomus badium, a new sporocarpic mycorrhizal fungal species from European grasslands with higher soil $\mathrm{pH}$. Angewandte Botanik 79: $38-43$

Olsen SR, Cole CV, Watanabe FS, Dean LA (1954) Estimation of available phosphorus in soils by extraction with sodium bicarbonate. U.S. Department of Agriculture Circ. 939

Ramette A (2007) Multivariate analyses in microbial ecology. FEMS Microbiol Ecol 62:142-160

Rivera R, Fernández F, Fernández K, Ruiz L, Sánchez C, Riera M (2007) Advances in the management of effective arbuscular mycorrhizal symbiosis in tropical ecosystems. In: Hamel C, Plenchette $\mathrm{C}$ (eds) Mycorrhizae in crop production: Applying knowledge. Haworth, Binghampton, pp 151-196

Ryan MH, Graham JH (2002) Is there a role for arbuscular mycorrhizal fungi in production agriculture? Plant Soil 244:263-271

Sano SM, Abbott LK, Solaiman MZ, Robson AD (2002) Influence of liming, inoculum level and inoculum placement on root colonization of subterranean clover. Mycorrhiza 12:285-290

Schreiner PR (2007) Effects of native and non-native arbuscular mycorrhizal fungi on growth and nutrient uptake of 'Pinot noir'
(Vitis vinifera L.) in two soils with contrasting levels of phosphorus. Appl Soil Ecol 36:205-215

Smith SE, Read DJ (1997) Mycorrhizal symbiosis. Academic, San Diego Ter Braak CJF (1986) Canonical correspondence analysis: a new eigenvector technique for multivariate direct gradient analysis. Ecology 67:1167-1179

Treseder KK, Allen MF (2002) Direct nitrogen and phosphorus limitation of arbuscular mycorrhizal fungi: a model and field test. New Phytol 155:507-515

van Aarle IM, Olsson PA, Soderstrom B (2002) Arbuscular mycorrhizal fungi respond to the substrate $\mathrm{pH}$ of their extraradical mycelium by altered growth and root colonization. New Phytol 155:173-182

Warnock DD, Lehmann J, Kuyper TW, Rillig MC (2007) Mycorrhizal responses to biochar in soil-concepts and mechanisms. Plant Soil 300:9-20

Young CC, Juang TC, Guo HY (1986) The effect of inoculation with vesicular-arbuscular mycorrhizal fungi on soybean yield and mineral phosphorus utilization in subtropical-tropical soils. Plant Soil 95:245-253

Zeuske D, Weber HC (2000) Growth stimulation of Panax ginseng C.A. Meyer (Araliaceae) arising from AMF-isolate inoculation. Symbiosis 29:213-23 